\title{
Fragment(s) of the Past
}

Archives, Conflicts, and Civic Rights in Algiers, 1830-1870 *

Isabelle Grangaud

Thirty-two years after the conquest of Algiers by the French army, the city had been stripped of much of its religious heritage. Of the 122 mosques that had stood in Algiers in 1830 , only twenty-one remained in 1862 , and of these only twelve were still operational: four out of thirteen large mosques and eight out of 109 small mosques. Of the thirty-two oratories associated with a saint's tomb, only nine remained, the rest having been destroyed or repurposed. As for the twelve zawiyas (study and residential centers), of the five that had not been demolished, not one still performed its original function. Thus, of the 166 religious institutions that had existed within the Ottoman city, only twenty-one remained in use. ${ }^{1}$ Two major interpretations have been advanced to explain this rapid deterioration. Traditionally, the leveling of these structures was considered to be one of the forms of violence wrought first by the war and then by the attempts at pacification that characterized the forty years between the start of the conquest and the beginning of France's Third Republic. According to this classic historiography popularized by Charles-André Julien, this large-scale destruction, which was later denounced, belonged to the messy prehistory of the colonial regime. ${ }^{2}$ More recently, François Dumasy has countered the idea that the early stages of colonization were uncontrolled. He has argued instead that the systematic demolition of the city of Algiers from

This article was translated from the French by Rosalind Holmes Duffy and edited by Robin Emlein, Chloe Morgan, and Stephen Sawyer.

* I would like to thank Sami Bargaoui, Simona Cerutti, Jocelyne Dakhlia, Brigitte Marino, Alain Messaoudi, James McDougall, and Michel Naepels, as well as the coordinators of this thematic dossier, for their comments on earlier versions of this text.

1. Albert Devoulx, Les édifices religieux de l'ancien Alger (Algiers: Typographie Bastide, 1870), 3.

2. Daniel Rivet, Le Maghreb à l'épreuve de la colonisation (Paris: Hachette, 2002), 101 sq.; Charles-Robert Ageron, Les Algériens musulmans et la France, 1871-1919 (Paris: Presses universitaires de France, 1968); Sylvie Thénault, “1881-1918: 1'“apogée' de l'Algérie française et les débuts de l'Algérie algérienne," in Histoire de l'Algérie à la période coloniale, 1830-1962, ed. Abderrahmane Bouchène et al. (Paris: La Découverte, 2014), 159-84. 
the first years of the conquest was both a demonstration of strength by the conquerors and a carefully wielded weapon used to strip the old inhabitants of their rights and ensure easy access to the city for the new arrivals. ${ }^{3}$ The two interpretations differ in the place that each accords to violence in the general economy of colonialization, but Dumasy also innovates in his shift towards recognizing the nature of the power dynamic that presided over the destruction of Algiers. With the French conquest, this dynamic was materialized in a dispute over the definition of civic rights. ${ }^{4}$ Dumasy's approach inserts acts of war into a landscape crisscrossed by antagonisms reflecting logics of disorder and confrontation that the teleology of pacification had never admitted. Nevertheless, such an approach has its limitations: this antagonistic situation appears as the conclusion of his research rather than its starting point, thereby reducing the undifferentiated violence of the destruction to a presupposition. The history of this power struggle, made palpable by the unveiling of this perpetually conflictual setting, remains to be written.

One of the major obstacles to exploring this history lies in the nature of the sources available. Colonial sources have been the subject of a renewed analysis, notably in postcolonial studies, regarding both the effects of domination and the conditions necessary for undertaking a historiographical project. Some scholars have pointed to the effects of the concealment and documentary suppression of the voices (and experienced reality) of the "colonized" caught up in the project of colonial domination-which made their retrieval that

3. François Dumasy, "Propriété foncière, libéralisme économique et gouvernement colonial : Alger, 1830-1840," Revue d'histoire moderne et contemporaine 63, no. 2 (2016): 40-61.

4. François Dumasy, "À qui appartient Alger? Normes d'appartenance et conflits d'appropriation à Alger au début de la présence française (1830-1833)," in Appartenance locale et propriété au nord et au sud de la Méditerranée, ed. Sami Bargaoui, Simona Cerutti, and Isabelle Grangaud (Aix-enProvence: IRENAM, 2015), 89-121, https://doi.org/10.4000/books.iremam.3454; Isabelle Grangaud, "Prouver par l'écriture: Propriétaires algérois, conquérants français et historiens ottomanistes," Genèses. Sciences sociales et histoire 74, no. 1 (2009): 25-45; James McDougall, "A World No Longer Shared: Losing the Droit de Cité in Nineteenth-Century Algiers," Journal of the Economic and Social History of the Orient 60, no. 1/2 (2017): 18-49. 
much more unlikely. ${ }^{5}$ Others have chosen to contrast the fundamentally Eurocentric episteme of the colonial corpus with "untainted" vernacular sources. ${ }^{6}$ Whichever the option, they have pressed the sources into service as mouthpieces for these various antagonisms and, as such, have solicited them, valued them, or denigrated them accordingly in order to make sense of the balance of power. Clearly, this poses numerous problems, including that of forcing sources into an order of battle. Rather than being coopted to a predetermined register, materials from the past are better understood as intrinsic elements of the conflict, since they themselves formed the locus for the active and complex development of the terms and mechanisms of the power struggle.

This article reconsiders the urban destruction of Algiers in light of one of its main episodes. It examines the conditions of the disappearance and abandonment of the city's religious structures following a struggle that pitted the agents of the Domain of Algiers's colonial administration against the beneficiaries of local resources generated by waqf (or $h a b \bar{u} s$ ), inalienable pious foundations endowed with the assets belonging to urban religious institutions. These trusts, responsible for financing religious, cultural, and charitable activities and for ensuring the continued existence of the establishments associated with them, constituted a sizable portion of the real estate of the city and therefore must have been particularly coveted during the conquest. Uncovering and retracing the history of this confrontation around the habūs is not easy, as its outcome rendered the terms of the conflict obsolete and provoked a general tidying up of the past that permanently obscured the underlying issues. Nevertheless, two "witnesses" can be brought to bear, both sources concerned with the Ottoman period before the French conquest. The first is The Religious

5. Nicholas B. Dirks, "Colonial Histories and Native Informants: Biography of an Archive," in Orientalism and the Postcolonial Predicament: Perspectives on South Asia, ed. Carol A. Breckenridge and Peter van der Veer (Philadelphia: University of Pennsylvania Press, 1993), 79313; Ann Laura Stoler, “'In Cold Blood': Hierarchies of Credibility and the Politics of Colonial Narratives," Representations 37 (1992): 151-89.

6. Dipesh Chakrabarty, Provincializing Europe: Postcolonial Thought and Historical Difference (Princeton: Princeton University Press, 2000); Romain Bertrand, L'histoire à parts égales. Récits d'une rencontre Orient-Occident (XVI - XVII ${ }^{e}$ siècles) (Paris: Éd. du Seuil, 2011). 
Edifices of Old Algiers, a major historical work by Albert Devoulx; the second is the "Ottoman collection," the primary precolonial archive in Algeria, which was first constituted by Devoulx. This historian and archivist, who died in Algiers in 1876, is thus the link that connects the two.

It is worth noting, however, that they are not "witnesses" because of what they tell us about the struggle that unfolded around the habūs; any literal reading of this narrative would be incorrect and would by and large overlook the sequence of events and what was at stake within them. What these sources have to offer is not so much the material they contain (le propos) as their very materiality — and the immaterial conditions of their creation and use by contemporary actors (l'à propos). Indeed, both works played a role in this struggle, which conditioned how they came into being and how they presented certain interactions, as well as shaping their content and form. More important still, they operated at the heart of the power struggle as it played out, providing a means to respond, affirm, and act that, in turn, nurtured the conflict. Reconstructing and contextualizing the origins of these two sources, examining the claims they conveyed and the interactions between them, makes it possible to retrace the history of the disappearance of the mosques of Algiers and, in turn, to appreciate the true nature of the sources themselves.

\section{0: A Preliminary Scholarly Work on Old Algiers}

The year 1870 saw not only the advent of the Third Republic in France but also the publication, in Algiers, of The Religious Edifices of Old Algiers, the first systematic and historically informed overview of an extensive series of buildings associated with devotional activities in the city and its immediate surroundings during the Ottoman era. ${ }^{7}$ This source remains extremely valuable to historians of the city, who find it to be an especially rich and

7. Devoulx, Les édifices religieux de l'ancien Alger. 
detailed reading of Ottoman monuments within the urban space of Algiers. ${ }^{8}$ As a study of the urban environment, this work is notable for the number of historical materials it mobilizes, making Devoulx a true pioneer in the labyrinthine project of collecting literary and archival documentation in Arabic and, to a lesser extent, in Ottoman Turkish. Devoulx's fingerprints can be found on every research project on the Ottoman past of Algiers because he spent years uncovering archival documents from that era, of which he clearly had extensive knowledge. Like many of the Arabists who were brought to the new colony by the military, the administration, or their studies, or who, like him, had grown up there, ${ }^{9}$ he was fascinated by these famous "authentic documents" that evoked the past and whose translation was central to his work. ${ }^{10}$

An early version of what eventually became The Religious Edifices of Old Algiers was published-as was the bulk of Devoulx's work-in the Revue africaine as a series of nine installments between 1862 and 1870. Devoulx was a prolific contributor to this journal, which was typical of periodicals produced by the learned societies that, with colonization, established footholds in Algeria. In this capacity, he was one of the in situ scholars whose work invigorated the Algerian Historical Society, which published the Revue africaine

8. See, for instance, Samia Chergui, Les mosquées d'Alger. Construire, gérer et conserver, XVI XIX ${ }^{e}$ siècles (Paris: Presses de l'université Paris-Sorbonne, 2011); Nabila Chérif-Seffadj, Les bains d'Alger durant la période ottomane, XVI $I^{e}-X I X^{e}$ siècles (Paris: Presses de l'université Paris-Sorbonne, 2008); Sakina Missoum, Alger à l'époque ottomane. La médina et la maison traditionnelle (Aix-enProvence: Édisud, 2003).

9. Born in Marseille in 1826, he arrived in Algiers before the age of five.

10. Devoulx published a number of such works, beginning with Tachrifat, recueil de notes historiques sur l'administration de l'ancienne régence d'Alger (Algiers: impr. du Gouvernement, 1852) and including Le rä̈s Hamidou, notice biographique sur le plus célèbre corsaire algérien du XIII siècle de l'hégire, d'après des documents authentiques et pour la plupart inédits (Algiers: A. Jourdan, 1859); Ahad Aman ou règlement politique et militaire (1860); La marine de la régence d'Alger (Algiers: impr. de Bastide, 1869); Le livre des signaux de la flotte de l'ancienne régence d'Alger (Algiers, 1868); Notices sur les corporations religieuses d'Alger (Algiers: impr. de Bastide, 1862); and finally Le registre des prises maritimes. Document authentique et inédit concernant le partage des captures amenées par les corsaires algériens (Algiers: A. Jourdan, 1872). These texts were supplemented by the compilation Archives du consulat général de France à Alger. Recueil de documents inédits concernant, soit les relations politiques de la France, soit les rapports commerciaux de Marseille avec l'ancienne régence d'Alger (Algiers: Bastide, 1865). 
beginning in $1856 .^{11}$ His arrival in this learned society (where for a time he served as treasurer) was recounted at his funeral in autumn 1876, following his death at the age of fifty. ${ }^{12}$ His eulogy, given by Ernest de Salve Villedieu, then rector of the Academy of Algiers, was focused on an effort of Devoulx's that was less well known, no doubt because he had not had time to publish its results before his premature death: a manuscript developed with the intention of applying for the prize of the Algerian Academy (established six years earlier). This comprehensive survey, abundantly illustrated, was devoted to "The archaeological investigation of the city of Algiers pertaining to its creation and development from the earliest stages to $1830 .{ }^{\prime 13}$ This indicates that Devoulx, by placing precolonial Algiers at the center of his preoccupations, pursued a scholarly endeavor for which he hoped to receive some recognition, and posterity has undeniably awarded it to him.

The patiently assembled contents of The Religious Edifices of Old Algiers confirm the erudite ambition of the project. The work is presented as an encyclopedia of the buildings that served religious functions in the city and its periphery. Its author identifies 194 structures: 166 intra muros (including the immediate surroundings of Bāb al-Wād, the gate at the north of the city) that receive individual entries and another twenty-eight (in the surrounding countryside) that form a brief list appended to the text. In the introduction, he explains his decision to present these buildings by means of a guided walk through the city. This principle of an informative tour through the streets makes it easier to comprehend the distribution of buildings in the environment and to account for the distances between them. The visit begins at Bāb al-Wād and follows a trajectory that rises through successive levels of the city before

11. Saddek Benkada, "Archéologie et entreprise coloniale. L'armée et les premiers travaux de topographie historique en Algérie (1830-1880)," in Savoirs historiques au Maghreb. Constructions et usages, ed. Sami Bargaoui and Hassan Remaoun (Oran: Éd. du CRASC, 2006), 225-35.

12. Alain Messaoudi, Les arabisants et la France coloniale. Savants, conseillers, médiateurs (1780-1930) (Lyon: ENS Éditions, 2015): "Devoulx, Joseph Marie Albert (Marseille, 1826-Alger, 1876)," online appendices, https://doi.org/10.4000/books.enseditions.3730.

13. This work was partially published a few years ago: Albert Devoulx, El-Djazaïr, histoire d'une cité d'Icosium à Alger, ed. Bedredine Belkadi and Mustapha Benhamouche (Algiers: ENAG Éditions, 2003). 
arriving at the Ottoman casbah at its westernmost point. Thus, while there was no map appended to the work, the sequence of the entries gives an approximate sense of the general layout of the urban space.

Each entry has the same format, giving the location and name of the building — or, in some cases, the names - and a description, when documentation could be sourced, of the circumstances of its establishment and how it evolved over time. In this "archaeological" reconstruction, the author sometimes draws upon his own memories, demonstrating his familiarity with these places. He also describes epigraphic engravings, giving their location (whether in a museum or on the building itself) and relates a few Arabic chronicles, travel narratives, and accounts of captivity ${ }^{14}$ as well as some gray literature produced by the city's French administration. In each entry there are verbatim passages from several of these sources. The inscriptions on the facades of the buildings are consistently recorded, and the transcribed Arabic text is followed by its French translation, as in the case of the "Mosque known as Kechaoua in the rue du Divan." ${ }^{15}$ It is less common to find citations from other published works, as the author set himself the task of "using only official documents," of which clearly accompanied him throughout the entire project. Devoulx regularly cites the detailed description of the city written by the Spanish Franciscan Diego de Haëdo after his capture in Algiers at the end of the sixteenth century. ${ }^{17}$ The other text is described as the "Manuscript of the son of the Hanafi Mufti Hossein Ben Redjeb," from which long passages on the "Great Mosque in the rue de la Marine" and the "Mosque known as Djama el-Djedid in the Place Mahon near the Fishermen's slipway"18 are excerpted and translated. Among all the sources assembled, however, the most numerous by far are excerpts from records drawn up by

14. Chronicles of this kind from the modern era were well known at the time, due to a large movement to discover and publish an array of texts concerning the Maghreb space.

15. Devoulx, Les édifices religieux de l'ancien Alger, 165.

16. Ibid., 99.

17. Diego de Haëdo, Topographie et histoire générale d'Alger [1612], trans. Dr. Monnereau and Adrien Berbrugger, with a preface by Jocelyne Dakhlia (Saint-Denis: Éd. Bouchène, 1998). The translation first appeared in several parts in the journal Revue africaine in 1870 and 1871.

18. Devoulx, Les édifices religieux de l'ancien Alger, 100 sq. and 143 sq. 
qadis. In each entry, following the documentary descriptions, there is a numbered list of what the author refers to as "indications" (renseignements) consisting of translated excerpts of notarized acts from the Ottoman era. The excerpts he has chosen are of varying length; in some cases deemed to be particularly interesting the entire act has been reproduced, but more often he excerpts just a few words about the building that is the subject of the entry (its name, for example). This selection of documents forms a heterogeneous collection of fragments, often tiny and meticulously reported, each taken from a source whose origin is unidentified, apart from the year it was produced. Thus, in these entries, the material description of the buildings is completed by an ensemble of documents drawn from all available sources, in various languages and from different periods, with the aim of being as exhaustive as possible. In gathering them together, special attention was given to the translation of fragments of archival and Ottoman sources, which embodied the intimate correlation between paper and stone. This was an unprecedented, systematic documentation of the monuments of Ottoman Algiers, and, although corrections have occasionally been made over the years, it has no equal.

The physical descriptions of these places of worship are as detailed as their functions are vague. One part of the introduction briefly describes the nature of the buildings, distinguishing the mosques from those that are referred to as "chapels" and "zawiyas," but Devoulx's typology reveals itself to be inconsistent and not terribly useful. ${ }^{19}$ The fact that the ensuing entries do not always manage to resolve these ambiguities suggests that the author did not fully understand his subject. The religious life of old Algiers is not his primary interest; his focus clearly lies in the physical remains of the past, by then half vanished, that had still

19. Ibid., 3-12. This shows that local languages did not make much of a distinction between "khutbah mosques" (which have a minaret and are allowed to give sermons on Fridays) and the others, which were much more numerous; that the chapels, also called kobba or "marabouts," which were attached to a saint's tomb (and sometimes also to a small cemetery) were sometimes referred to as zawiyas if there was also "a mosque or several other dependencies"; that there was a distinction between rural zawiyas (a chapel with a douar around it) and urban zawiyas, "which offer shelter to foreigners, students, and the poor, as well as lessons," although "some of them provide neither schooling nor shelter." 
dotted the cityscape forty years earlier. The materiality of these paper fragments echoes that of the stone and mortar of the buildings, now reduced to rubble.

The historical curiosity about the past that pervades this learned work thus seems to be selective. Undoubtedly, Devoulx sought to give his work an antiquarian form typical of nineteenth-century erudition, with its fondness for unearthing old stones and ancient texts, and he did so with success and in keeping with academic norms. He was also participating in a more general movement to uncover the colony's past. Devoulx's undertaking was not colored by nostalgia - frankly, there is not a hint of it to be found anywhere in his work- nor did it reflect the least bit of value assigned to these stones. Devoulx shows little admiration for the buildings themselves; on the contrary, he points out their architectural mediocrity on multiple occasions. On the other hand, this indifference is counterbalanced by a particular sensitivity to the state of ruin to which this heritage had been reduced. In fact, the most substantially documented portion of each entry concerns the recent past of these buildings. With great precision, Devoulx reports on the fate of each structure at the moment he is writing: the conditions of their destruction, their replacement, or their new use following occupation. So what was Devoulx's purpose in writing this book? What experiences gave rise to his interest in the religious urbanism of the city and its fate in the wake of the conquest? Further, what was the provenance of the archival materials from the Ottoman era that he was using, and how did he learn of their existence? Finally, what meaning did he assign to this scholarly endeavor? If we are to attempt to answer these questions, we must consider the activities that brought him into contact with the mosques and the corresponding Ottoman archival documents, namely his work for the administration of the Domain of Algiers.

\section{Devoulx and Son: Arabists in Service to the Domain of Algiers}


Devoulx's scholarly work developed in contact with the administration of the Domain of Algiers, in which the largest part of his life unfolded. He entered into its service in 1848, at the age of twenty-two, and remained until his death in 1876. He undoubtedly forged enduring relationships there, and when he married in 1852, his witness was none other than the Domain's director, Jean-Baptiste Fabre. These relationships were also familial; several months earlier, the same witness had presided over the wedding of Albert's sister. When he began working for the administration of the Domain, it was already familiar territory for him, as his father Alphonse had worked there as a "receiver of public territories and revenues" starting in February 1831, four months after this administration began. In fact, it seems to have been this assignment that brought Alphonse Devoulx to Algiers, where he settled permanently with his family. Born in Fiume and raised in Marseille, he had been a merchant in Tunis since the start of $1829 .{ }^{20}$ On February 5, 1830, his mother, wife, and two children joined him in Tunis, before moving to Algiers the following year.

At the end of the 1820s, the French consular community in Tunis, with Mathieu de Lesseps at its center, was active in preparing for the French invasion of Sidi Ferruch (Sidi Fredj) on July 5, 1830, and in supporting the Algerian conquest. To this end, a certain Prosper Gérardin had been sent in April to join the consul general. ${ }^{21}$ This same Gérardin, an Arabic interpreter, was to become the first director of the administration of the Domain of Algiers. It is highly likely that Alphonse Devoulx's time in Tunis and within this consular milieu gave him an opportunity to develop Algerian projects and connections. We know that he socialized with the consul's son, ${ }^{22}$ and this is probably where he met Gérardin, whom he followed to

20. Anne-Marie Planel, Du comptoir à la colonie. Histoire de la communauté française en Tunisie, 1814-1883 (Paris/Tunis: Riveneuve Éditions/IRMC, 2015), 716-17. This section owes a great debt to Messaoudi, who generously allowed me to use the results of his own archival research on the Devoulx family.

21. Gérard-Roger Busson de Janssens, "Contribution à l'étude des habous publics algériens" (PhD diss., Université d'Alger, 1950), 44.

22. Alphonse Devoulx, "Voyage à l'amphithéâtre d'El-Djem en Tunisie (janvier 1830)," Revue africaine 18 (1874): 241-61, here p. 260. 
Algiers a year later. They also had in common their knowledge of the Arabic language - an indispensable skill for those involved in the Domain's nascent administration.

The Domain was in fact first and foremost a province of language experts. Prior to its founding in September 1830, a "domain committee" had been nominated on July 17 (within the initial government commission, established the day after the fall of Algiers on July 5). This committee was composed of three members, all seasoned Arabic speakers: its president, the famous Gérardin who had been in Tunis just a few weeks before, and two local luminaries, Sīdī Muṣtafā Shawush and Muhammad Qubtạn. ${ }^{23}$ Its role was to identify debtors and claim the rights of the state by carefully sifting through Ottoman records. Indeed, this was the initial mission of the administration of the colonial Domain in Algiers, established several weeks later as an extension of this committee: since France had replaced the dey, it was necessary to recover the debts owed to him for the benefit of the new authority and determine the "public" assets to which it could lay claim. This required a staff that was capable of understanding documentation from the Ottoman period, which was in Ottoman Turkish and, above all, Arabic. ${ }^{24}$ Alphonse Devoulx was assigned to Gérardin's new administration at the start of 1831, at a time when Arabists in the interpreter corps of the African Army, temporarily mobilized, were in short supply, and Arabists outside their ranks were called in out of necessity. ${ }^{25}$ It is most likely in these circumstances that Alphonse, who in Fiume, Marseille, and then Tunis had been immersed in the world of trans-Mediterranean trade, found himself in Algiers. He did not belong to any professional body of interpreters, and despite his good understanding of Arabic (acquired in unknown circumstances) and his later specialization in the field of Algerian documentation, this absence of affiliation may have

\footnotetext{
23. Aix-en-Provence, Archives nationales d'Outre-Mer (National archives of France's overseas territories, hereafter "ANOM"), carton F80-1670A, "Commissions du Gouvernement, procèsverbaux." Monsieur le baron Denniée, president, minutes July 17, 1830. This text uses different spellings: Sidi Mustapha Chaou and Mohamed Kubtan.

24. This search monopolized the Domain administration's correspondence during the first years of conquest: ANOM, carton F80-1057, "Correspondances 1831-1832."

25. Messaoudi, Les arabisants et la France coloniale, 148.
} 
handicapped his career. ${ }^{26}$ At the very least, his son Albert, following in his footsteps and with his clear encouragement, ${ }^{27}$ benefited from a much more stable trajectory. He received a thorough training in Arabic at the Colonial School in Algiers, which, following a short stint as a student interpreter in the Administration of Finance at age seventeen, gave him his lasting entrée, five years later, into the Domain's administration. ${ }^{28}$ In 1848 , he was assigned to head the Office of Arabic Archives as a curator. Thus, like his father before him, it was Albert's linguistic background that brought him into the service of the colonial administration. The Religious Edifices of Old Algiers and, more largely, his published work as a whole, are indebted both to Devoulx's skills as an Arabist and to the environment in which he exercised them. In effect, of the two interpreters who worked under his supervision, Muhamamad Khūja ibn Muștafā and Muḥammad Nawūsh, at least one, the former, also helped with his translation projects. $^{29}$

Language was certainly not the only thread connecting Devoulx the city historian and Devoulx the Domain agent. Other overlaps appear when one considers the environment in which he would have exercised his administrative activities. Despite what its name suggests, the Office of Arabic Archives had a function that went beyond the simple conservation of documents. It was in fact the place where Domain agents pursued the original mission of the

26. The tensions between the prestigious body of professional interpreters and those working in the field are explored in Messaoudi, Les arabisants et la France coloniale, 143-49; Messaoudi, "Renseigner, enseigner. Les interprètes militaires et la constitution d'un premier corpus savant 'algérien' (1830-1870)," Revue d'histoire du XIX siècle 41 (2010): 97-112. See also LaurentCharles Féraud, Les interprètes de l'armée d'Afrique (archives du corps) suivi d'une notice sur les interprètes civils et judiciaires (Algiers: A. Jourdan, 1876), which sets out to defend the prestige of the professional community to which the author belonged.

27. Tachrifat, published under the name of Albert Devoulx in 1852, seems to have been the work of his father: Gaëtan Delphin, "Histoire des Pachas d'Alger de 1515 à 1745. Extrait d'une chronique indigène," Journal asiatique, 11th ser., 19 (1922): 161-233, here p. 180. It was strategically dedicated to the governor-general.

28. On Devoulx's training, see Messaoudi, Les arabisants et la France coloniale, entry "Besnier"; ANOM, carton F17-7677, "Rapport d'Artaud, inspecteur général des études, au Ministre de la Guerre, président du conseil, sur l'enseignement de la langue arabe aux Français et de la langue française aux Indigènes en Algérie, Alger, 30 nov. 1842," cited in Messaoudi, Les arabisants et la France coloniale, entry "Alphonse Devoulx."

29. Delphin, "Histoire des Pachas," 183; Messaoudi, Les arabisants et la France coloniale, entry “Albert Devoulx"; Devoulx, Tachrifat, 5. 
administration, namely research in view of reclaiming public properties. When Devoulx was assigned to his post, his mission was to "gather documentation to support the state's claims. ${ }^{\prime 30}$ Specifically, this project targeted a particular type of property, the habūs-also known as awqāf (sing. waqf) or "habous," according to the Gallicized term then in usewhich were religious foundations entrusted with the wealth of the mosques. ${ }^{31}$ But first, it is important to understand the political significance of these assets in the constitution of the Domain's colonial administration from 1830.

\section{The Domain and the Habūs}

By the time Devoulx was appointed to the Office of Arabic Archives, the Domain had already undergone a lengthy transformation since its establishment in Algiers. Its functions had been expanded to include a Department of Land Registration and Estates, and its scope had grown to include all conquered cities. ${ }^{32}$ This structure was thus charged with managing a considerable amount of public property, which had been circumscribed and consolidated through a series of ordinances issued during the 1830s. The devolution of real estate to the French state as stipulated in the dey of Algiers's treaty of surrender of July 5, 1830—which was the Domain's main preoccupation in the early years of the conquest—ran up against the fact that public property was not extensive and was limited by the existence of assets that largely escaped the public purview: private property, or habūs. In addition, recovering these properties proved to be challenging for the colonists. The array and entanglement of rights that could apply to a single structure (multi-level properties, joint ownership, collective

30. Delphin, "Histoire des Pachas," 174.

31. The habūs were inalienable endowments organized for the benefit of cultural institutions, hospitals, and charities, or for public services like urban water supply systems, bridge construction, barracks, roads, and walls. Before a donor made an endowment to the charitable institution of his choice, he could specify the beneficiaries of usufruct rights to the properties placed in the habuss trust.

32. The evolution of this institution can be pieced together using documents relating to other periods of reorganization during the Domain administration: ANOM, carton F80-991, "Enregistrement domaines : organisation, 1833-1848." 
ownership, etc.), on the one hand, and the principle of inalienability attached to habus, on the other, were a considerable obstacle to the transfer of property to the colonists. The project of reclassification that they undertook, which initially fell to the administration rather than legal experts, ${ }^{33}$ profoundly changed the nature of property rights from before the conquest. ${ }^{34}$ And the earliest targets of these attacks were, without a doubt, the impressively large habuss endowments of religious institutions. ${ }^{35}$ By the end of the 1840 s, they had all become part of the Domain's public property.

The main steps in the administrative decision-making that enabled this process of alienation are known to us. ${ }^{36}$ On December 7, 1830, it was decreed that all habūs comprising the endowments of pious institutions were to be managed by the Domain. ${ }^{37}$ Chief among these was the habūs of "Mecca and Medina," an Ottoman institution in Algiers dedicated to

33. David S. Powers, “Orientalism, Colonialism, and Legal History: The Attack on Muslim Family Endowments in Algeria and India," Comparative Studies in Society and History 31, no. 3 (1989): 535-71; Jean-Philippe Bras, "L'imperfection de la propriété indigène, lieu commun de la doctrine juridique coloniale en Afrique du Nord," in Bargaoui, Cerutti, and Grangaud, Appartenance locale et propriété, https://doi.org/10.4000/books.iremam.3441.

34. Isabelle Grangaud, "Dépossession et disqualification des droits de propriété. Le droit colonial au service des spoliations à Alger dans les années 1830," in Bouchène et al., Histoire de l'Algérie à la période coloniale, 70-76; Grangaud, "Prouver par l'écriture"; Grangaud, "Affrontarsi in archivo. Tra storia ottomana e storia coloniale (Algeri 1830)," Quaderni storici 43, no. 129 (3) (2008): 62152. On the requalification of property, see Didier Guignard, "Le sénatus-consulte de 1843 : la dislocation programmée de la société rurale algérienne," in Bouchène et al., Histoire de l'Algérie à la période coloniale, 76-81; Guignard, "Les inventeurs de la tradition 'melk' et 'arch' en Algérie," in Les acteurs des transformations foncières autour de la Méditerranée au XIX siècle, ed. Vanessa Guéno and Didier Guignard (Paris/Aix-en-Provence: Karthala/MMSH/IRENAM, 2013), 49-93.

35. Tal Shuval, "Poor Quarter/Rich Quarter: Distribution of Wealth in the Arab Cities of the Ottoman Empire: The Case of Eighteenth Century Algiers," Turcica 32 (2000): 169-96, here p. 177: "the private ownership of houses in Algiers in the eighteenth century [was] the exception rather than the rule, for most Algerians lived in rented waqf houses"; Miriam Hoexter, Endowments, Rulers, and Community: Waqf al-Haramayn in Ottoman Algiers (Leiden: Brill, 1998), 43-48.

36. The most complete account of these stages is the unpublished but extensively cited work by the lawyer Busson de Janssens, "Contribution à l'étude des habous publics algériens"; John Ruedy, Land Policy in Colonial Algeria: The Origins of the Rural Public Domain (Berkeley: University of California Press, 1967); Rachid Ouahres, "Le forum et l'informe. Projet et régulation publique à Alger (1830-1860)" (PhD diss., Université Paris VIII, 2006); Maaoudia Saidouni and Nacereddine Saidouni, "Il 'waqf' in Algeria e l'amministrazione francese: il caso della fondazione degli 'Haramayn' (Algeri 1830-1873)," Quaderni storici 44, no. 132 (3) (2009): 687-726; CharlesLouis Pinson de Ménerville, Dictionnaire de la législation algérienne. Code annoté et manuel raisonné des lois, ordonnances, décrets, décisions et arrêtés publiés au Bulletin officiel des actes du gouvernement, vol. 1, 1830-1860 (Algiers/Paris: Bastide/Cosse et Marchal, 1866); Alfred Franque, Lois de l'Algérie, du 5 juillet 1830 (occupation d'Alger) au ler janvier 1841 (Algiers: Dubos et Marest, 1844).

37. Decree of September 7, 1830, issued by General Clauzel, article 1. See Busson de Janssens, "Contribution à l'étude des habous publics algériens," 48; Franque, Lois de l'Algérie, 7; ANOM, carton F80-1670A, analytical table of the decrees of the government of Algiers, article 49. 
aiding the poor of the two holy cities (haramayn), which was by far the richest foundation of the city and, more generally, of the regency. ${ }^{38}$ This decree was actually a correction to an earlier decision, issued on September 8, that had recommended the outright absorption of this institution's properties into the Domain: henceforth, the Domain granted itself the right to review the management of these properties and of all the assets of the city's mosques. From 1835 onwards, the establishment of a new administrative entity, the Department for the Management of Habous, installed on the premises of the "Mecca and Medina" foundation, was created to increase the state's control over the management of these assets and to facilitate its takeover of the properties of destroyed, occupied, or abandoned mosques. A further development in two stages took place in 1839. As of January, the administration of buildings no longer depended on the Department for the Management of Habous but was transferred to the Administration of Finance. On August 21, a royal decree "on the organization of the financial regime of Algeria" redefined the structure of the Domain (by distinguishing between the State Domain and the Colonial Domain) and dealt a death blow to the very nature of the habūs, which had until then been protected by a recognition of their specific purpose. The inalienable character of these assets was altered with their assimilation into the Domain: the appropriation of the habuss, which until then had been excluded, had now become possible, albeit subject to gubernatorial decree. ${ }^{39}$ The 1840 s marked the wholesale incorporation of the habūs endowments into the Domain. Two decrees were issued, in 1843 and 1848 , to aid this process. The first stipulated the necessity of "placing all buildings of this kind under Domain administration." the administrators of the habūs trusts of religious institutions ten days to gather together "all

38. Devoulx, Notes sur les corporations religieuses d'Alger, 13; for a presentation of the valuation of the habūs properties of "Mecca and Medina" at the moment of the conquest, estimated at "more than half, maybe even three quarters or four fifths of all the waqf properties in and around Algiers," see Saidouni and Saidouni, "Il 'waqf' in Algeria e l'amministrazione francese"; Hoexter, Endowments, Rulers, and Community, 43 sq.

39. Busson de Janssens, “Contribution à l'étude des habous publics algériens," 73.

40. Ibid., 85. 
the buildings that until now have escaped state oversight," and to transfer to the Domain all documents pertaining to their prior management. ${ }^{41}$

Simply reading these collected decrees and declarations, mere cogs in the machine for reclassifying Algiers's real estate, does not do justice to just how violent and chaotic the process of transforming habūs into public property actually was-a process that bore the traces of a fifteen-year silent struggle that affected the entire social, economic, and political organization as it had existed prior to the conquest. The colonial authorities made their choices in a context of intense conflict and had great difficulty gaining access to the mosques' endowments, which explains why this process was so slow. The various administrative actors naturally applied the logic of their own conceptions: they set their sights specifically on the individuals who managed the habūs, identified in the language of the administration with the Gallicized term "oukils." Undermining the "oukils" was the first, and most radical, episode in this struggle, and its most notable result was to enduringly obscure the past.

\section{The Struggle against the "Oukils"}

Although it took place long before Devoulx entered into the Domain's service, the struggle against the "oukils" is present in The Religious Edifices of Old Algiers. It is the "oukils," rather than the social or religious functions of the institutions, whose history the author retraces and who provide the common thread orienting the whole work:

Because they are pious in nature or serve a public function, and especially because they possess an endowment administered by an oukil, I have included in this study establishments that do not belong to any of the three categories on which I have focused: these are schools, cemeteries, tombs, shelters, and public latrines. ${ }^{42}$

41. Ibid., 88.

42. Devoulx, Les édifices religieux de l'ancien Alger, 13. 
The "oukils" were Devoulx's main interlocutors when he entered into the service of the Domain. If the power struggle with them is so evident in his work, it is because the bulk of the material in The Religious Edifices of Ancient Algiers originated in this process. The struggle between the managers of the habūs assets and the administrative agents of the Domain effectively led those agents to engage in an intense activity of collecting and classifying evidence in order to quantify the mosques' wealth and requalify it in the eyes of the law. The considerable amount of documentation in Arabic produced as a result became a major weapon in this struggle. Devoulx was clearly one of the principal actors in this work. He became involved towards the end of the process that definitively annexed the habūs to the Domain, but his activity and the institutional framework he was to oversee derived wholly from the earlier stages. Devoulx was named head of the Office of Arabic Archives specifically to enact the 1848 decree. His predecessor was Hafiḍ Khūja, who had held the post since 1844 and was none other than the agent who, several years earlier, had been assigned to the Department for the Management of Habous as "Oukil of Mecca and Medina." The Office of Arabic Archives became an extension of this department and would be the authority that presided over the final stage in the assimilation of the habūs properties into the Domain.

The logic that had prevailed over this gradual absorption was not the result of an institutional decision to place the habūs outside the law, which would only be the case from the 1880 s. $^{43}$ Thus, the contestation by the French of the forms of property and appropriation prevalent in Algiers before 1830 did not reside in the incompatibility of local legal forms with French law, as was later argued in order to justify the wholesale process of dispossession that occurred during the first forty years of colonization. Multi-level, joint, collective, and inalienable properties: these notions of ownership were eminently familiar to the French of the mid-nineteenth century. In the case of the habūs, their dissolution was justified not as a

43. For a minute analysis of this process through a comparative reading of early colonial scholarship on "Islamic law" in French Algeria and British India-showing local variations as well as their larger influence - see Powers, "Orientalism, Colonialism, and Legal History." 
function of the legal status of these properties themselves but by the hic et nunc nature and conditions of their management. The delegitimization of the forms of management that had hitherto prevailed not only triggered their confiscation by the Domain, but also a questioning of the distinction between habūs that were simply in the public domain and those under the control of the state. Finally, it was not the normative order in itself that was discredited so much as the "oukils," who were deemed incapable of respecting it. ${ }^{44}$

The theme of the supposed incompetence of the "oukils," or of their unwillingness to assume their responsibilities, provided the principal argument for how the habūs properties were considered in correspondence and reports from the Domain's administrators. The authorities, using what information they had, rapidly concluded that the revenue from these properties in Algiers was low. On August 22, 1831, the administrative director of the Domain, Gérardin, signaled his skepticism, observing that, "to speak only of Algiers, it is ridiculous to think that the assets that Mecca and Medina possess in this city earn a sum total of only 21 francs on average." 45 On the whole, revenues had collapsed with the conquest, the war, and subsequent destruction. But although these considerations were sporadically mentioned, this situation fed suspicions of deception and fraud against the administrators of these estates. One event soon corroborated this theory: following the taking of Bône (now Annaba) and Oran, the Domain immediately assumed direct management of the habūs located there, as the inhabitants had almost entirely deserted, leaving the institutions and their estates vacant. ${ }^{46}$ These buildings, rented to Europeans, proved to be much more profitable. The comparison of these two modes of administration underscored not only the financial discrepancy, but also an opacity of management that the colonial agents took as an indication of fraud. Their oversight

44. For a comparable process in a different region, see Norbert Oberauer, “'Fantastic Charities': The Transformation of 'Waqf' Practice in Colonial Zanzibar," Islamic Law and Society 15, no. 3 (2008): 315-70.

45. Cited in Busson de Janssens, "Contribution à l'étude des habous publics algériens," 66.

46. Ibid., 59, citing a report of the 1833 investigative committee drawn up on January 12, 1834:

"Rapport sur la fondation de La Mecque et Médine et autres établissements pieux." 
was hindered by administrative forms that they judged to be anarchic and disorganized, as suggested by descriptions of charitable activities that emphasize a sense of chaotic arbitrariness:

Twice a week, eighty boudjous (144f[rancs]) leave the Mecca and Medina accounts as expenses, under the title of distribution of alms. No formalities govern these distributions. The oukil, accompanied by his chaoux carrying bags full of coins, goes into a shop where the coins are poured into a vase. The chaoux takes handfuls of coins and goes into the street to distribute one, two, or three coins to each poor person, with the exception of ten of them who receive three or five boudjous each week; the shop closes again and the oukil is eighty boudjous (2880 sous) lighter! $!^{47}$

Oversight was also hampered by a system of management that, during the Ottoman era, did not keep regular written records. According to Devoulx, "the oukils were not subject to any form of accounting or records. Taking full advantage of this permissiveness, they collected revenues from the endowments and spent them without making the slightest note, without even really knowing the exact state of their affairs themselves."48

In addition, the bookkeeping, as far as the Domain's administrators could judge, seemed to be fundamentally unusable: "the books were kept in such a state of disorder and total confusion that without first undertaking an audit, it would have been impossible to form any exact idea of the nature and extent of the properties [of the two holy cities of Mecca and Medina]," lamented one agent in a letter dated September 19, $1835 .{ }^{49}$ The majority of these findings pertained to the management of the properties of "Mecca and Medina," which were

47. ANOM, carton F80-1082, "Rapports généraux sur le Bey il mal et les corporations musulmanes," 1837. The chaoux (shawūsh) were ushers.

48. Devoulx, Les édifices religieux de l'ancien Alger, 15.

49. ANOM, carton F80-1082, "Rapport sur l'administration des corporations adressé à Monsieur l'Intendant civil," September 19, 1835. 
the first to be examined. ${ }^{50}$ But the administration soon came to see a lack of probity and a propensity to abuse as hallmarks of the "oukils" in general:

It is obvious to all observers that in an effort to abide by customs and recognize the property rights of the mosques, we are delivering immense revenues into the hands of a small number of men who exploit the properties with which they are entrusted for their own benefit, enrich themselves while adopting an attitude of beneficence, avoid paying expenses for the domain that they administer and disrespect its original functions, and make a mockery of our supposed oversight, whose sole result is that we ourselves assume responsibility for the corruption of their administration and the animosity it has engendered. ${ }^{51}$

This situation — as most of the people involved soon agreed - resulted from an administrative failing that dated back to the Ottoman period. Devoulx, in his 1870 work, summarized it thus:

How the oukils fulfilled their obligations was not subject to any official oversight. Public rumor was the only way of signaling to concerned parties those who, preferring the delights of the present to the promised rewards of the afterlife, swelled their fortunes to the great detriment of the upkeep of the temples that they administered. ${ }^{52}$

This conviction was enshrined as policy, with the main steps in the confiscation of institutional property coinciding with the successive discrediting of the "oukils." Believed to be dishonest, the administrator of the habūs trust of the two holy cities was dismissed, and the management of these properties was reassigned to the Domain's agents in 1835. For the same reasons, two years later, the properties of another powerful Algerian institution, the subūl khayrāt, were reattributed in the same way. ${ }^{53}$ In 1843 , the dismissal of the Great Mosque's “oukil," suspected of "resistance" (to colonial authority), was used to justify the publication

50. This institution, in many cases, functioned as an implicit reference model, when in fact it was a rather exceptional example in the urban economy of Ottoman Algiers.

51. ANOM, carton F80-1082, "Rapports généraux sur le Bey il mal et les corporations musulmanes," 1837.

52. Devoulx, Les édifices religieux de l'ancien Alger, 9.

53. Literally "the right ways." This institution combined the habūs of six mosques and two zawiyas, all attached to the Hanafi school of law. Zakia Zahra, "D'Istanbul à Alger : la fondation de waqf des Subūl al-Khayrāt et ses mosquées hanéfites à l'époque ottomane (du début du XVIII siècle à la colonisation française)" (PhD diss., Université d'Aix-Marseille, 2012). 
of the ordonnance that absorbed the habūs of all the mosques and other religious establishments into the Domain. In a general sense, the discrediting and delegitimization of the "oukils" was an efficient way to formalize their replacement by French authorities. The Domain presented its seizure of these properties as measures for public safety and order, against a handful of dishonest men. It also stepped in regularly to preempt habuss upon the death of their administrators, a "soft" option that seems to have been preferred over sudden, systematic change, "out of a desire to spare certain sensibilities." 54 This method was also used as a justification: "the death of the current 'oukils," wrote Léon Blondel, director of the Domain in 1843, "should be considered a sufficient motive for prompting incorporation., This delegitimization was without regard for an internal social logic that was struggling to survive.

\section{A Corporate Autonomy}

Mosques, oratories, and zawiyas (as well as schools, cemeteries, tombs, asylums, and "public latrines"): "each of these buildings was a distinct, self-sufficient establishment, due to its endowment or its donations from the faithful, and was administered by an oukil, a Gallicized word that I will use here instead of its French equivalents, gérant (manager) or administrator," ${ }^{, 56}$ wrote Devoulx. But who exactly were these "oukils"? Understanding their point of view in the struggle to control the mosques becomes more difficult when we try to grasp the nature, meaning, and modes of interaction underlying the conflict. Charles-André Julien's obvious cynicism towards one of the few figures who has not been entirely forgotten suggests the impossibility of this task ${ }^{57}$ : "Sī Hamdan would have been forgotten, just like the Moors who played a role in Algiers and Paris, were it not for publication in 1833 of his

54. Busson de Janssens, “Contribution à l'étude des habous publics algériens,” 86.

55. Ibid., 87.

56. Devoulx, Les édifices religieux de l'ancien Alger, 8.

57. McDougall, "A World No Longer Shared"; Jocelyne Dakhlia, "1830, une rencontre?" in Bouchène et al., Histoire de l'Algérie à la période coloniale, 142-48. 
Historical and Statistical Overview of the Regency of Algiers, titled The Mirror in Arabic."58

There is, in the colonial archives, a loquacious partiality that tends from the outset to fix the terms of debate by favoring a logic that glosses over the era's conflicts. Only by shedding this logic, by combing the sources for evidence of the thinking behind them, can we get to the heart of the conflict and thus begin to understand its nature.

The key to exploring this angle lies in a bundle of documents in Arabic collected by the Domain's agents in the course of their work. ${ }^{59}$ This bundle was probably assembled gradually, as documents were received, and they concern largely the same subjects. The fiftyfour pamphlets are of various sizes (they are generally folded sheets of parchment, the longest measuring more than two meters), and the writing is different and of varying quality from one author to the next. These documents provide accounts related to the management of the habūs. All in all, forty-four reports were filed (and most likely numbered later on). Each was the work of a delegate or wakil — the origin of the French term "oukil"—designating a person attached to the administration of the inalienable foundations or habūs of a building (a mosque, zawiya, or mausoleum $[k u b b a]$ ); of the institution of the "two holy cities" of Mecca and Medina or of several other establishments (as in the case of the subūl khayrāt); or of a corporation (such as that of the Great Mosque's muezzins [muwazin]). There is no doubt that this documentation was the result of an injunction (only partially enforced) by the French administration, ${ }^{60}$ as is clear from the similarities between the information given in each pamphlet. The nature of each habūs property is specified: house, small house (duwīra), story ('ulwā), shop, commercial or industrial premises (hanūt, dukkān, makhzin; farn), garden or

58. See Charles-André Julien, Histoire de l'Algérie contemporaine. La conquête et les débuts de la colonisation (1827-1871) (Paris: Presses universitaires de France, 1964), 74. As well as a book, Hamdan Khodja produced a number of reports addressed to the minister of war: Khodja, Le miroir. Aperçu historique et statistique sur la Régence d'Alger (1833; repr. Paris: Sindbad, 1985); Vincennes, Service historique de la défense (Ministry of Defense archives, hereafter "SHD”), 1H20, "Mémoire de Hamdan Khodja à l'adresse du Ministre de la guerre."

59. ANOM, archives of the former Regency of Algiers, reel 1Z.21, 1-55.

60. Fewer than half of the mosques in the city figure in this documentation. Furthermore, only the rural buildings, the market gardens of "Mecca and Medina," and those of the Great Mosque were accounted for. 
terrain. The location of each building is indicated with reference to the toponyms of the new street network (systematically designated by the term $s \bar{u} q$ [market]), and the number supplied in Arabic numerals. Also given are the corresponding annual or monthly rents, in addition to the type of contract: a perpetual rental ( $a n \bar{a})$, which was one of the most typical forms of rental on habüs properties, or a limited rental (kirā'). Finally, the name of each mosque is followed by the name of its steward.

These accounts were not all compiled at the same moment. The oldest, dated December 16, 1830, is written in the elegant script of the wakil of the subūl khayrāt, the sayyid Hasan bin al-Sayyid 'Alī Qulā'idjī. It was undoubtedly drafted in response to the decree published several days earlier, on December 7. The following year, the same wakil presented the accounts for the period between the first day of jumāda ath-thāni 1246 to the first day of jumāda ath-thān̄i 1247 (November 17, 1830-November 5, 1831). ${ }^{61}$ The document attributed to the wakil of the sacred sites of "Mecca and Medina" is not dated, but it was probably also produced at the end of December 1830. These reports did not, however, result from the bringing to heel of the institutions they concern: if this were the case, it would be unclear why they include accounts (albeit partial) relating to the habūs of the Great Mosque, whose endowments did not come under Domain control until 1843. The reports of the wakill-s responsible for the properties of the mosque and of its muezzins, respectively, were nonetheless compiled as of May 1831. Evidently, the accounts for these institutions or groups of institutions, the largest in the city, were given priority.

The other reports, totaling around forty, were compiled later, between February and April 1833. Judging from Devoulx's assessment of the quality of these structures, they were humble, without prestige, and suggestive of an economically depressed region. In fact, many

\footnotetext{
61. Upon the request, he informs us, of the Maliki qadi $(q \bar{a} d \bar{\imath})$, the shaykh al-Imām, al-Sayyid Muștafā bin al-Sayyid Muhammad. A third undated document that likely came from the same individual concerns the state of the habūs revenues of one of the mosques, the jāmi' Khadār Bāshā. We do not know whether it was drawn up before or after its occupation in 1831, but this detail would suggest the latter.
} 
of the buildings discussed in the 1833 declarations functioned as neighborhood mosques, and their endowments were usually small. Yet if we consider the way in which the wakìl-s referred to themselves, they seldom failed to mention their status as sayyid, an honorific indicative of a special rank. ${ }^{62}$ Similarly, the genealogies explicitly detailed by some of them point to established social positions. The majority did indeed come from the city's notable families, often property owners in positions of judicial and civic responsibility. ${ }^{63}$ Their members might manage multiple establishments, as was the case of sayyid 'Abd al-Rahmān ibn al-Shaykh ibn Dja'dūn, who was responsible for both a zawiya and a mosque (Zawiya Mawla Hasan and Masjid al-Katshawa), and whose brother sayyid 'Alī ibn al-Shaykh ibn Dja'dūn presided over the accounts of another mosque, 'the jāmi' above the hammam of sūq as-Sman." The Domain agents' scrutiny of the economy of urban establishments, evidenced by this bundle of documents, offers a glimpse into the involvement of the city's well-to-do - those same notables described in colonial reports as "cunning" and "dishonest."

The term wakil is sometimes used to identify the authors of these reports, but this is far from systematic. The meaning of the term in Arabic is actually fairly generic: it can be used interchangeably for a manager, delegate, or representative, depending on contractual modalities that are largely context-specific. In Ottoman Algiers, wakìl was used to designate a business agent for the dey as well as a one-time proxy authorized to act in a legal capacity for another individual. The reports instead often favor a formula that emphasizes the element of "responsibility" (bi-yad) attached to this role. More than just a treasurer, the person who shouldered this responsibility functioned as a legal guardian, a role that not everyone was capable of assuming.

62. Isabelle Grangaud, "Le titre de Sayyid ou $S \bar{\imath}$ dans la documentation constantinoise d'époque moderne: un marqueur identitaire en évolution," Revue des mondes musulmans et de la Méditerranée 127 (2010): 59-75.

63. Although these people are largely unknown today, the importance of the positions, alliances, and commercial undertakings of the families for whom we have documentation corroborate these social positions. Fatiha Loualich, La famille à Alger, XVII - XVIII siècles. Parenté, alliances et patrimoine (Saint-Denis: Éd. Bouchène, 2016). 
The colonial administration justified its demand for the "oukils"” accounts by arguing that their appointment (or removal) had hitherto been decided solely by the prince. Devoulx, for instance, was in no doubt that the "oukils" had received their mandate through nomination by the dey, even if his negligence had rendered this system obsolete and enabled its abuse. This conviction was founded on the rare existence of certification from deys ${ }^{64}$ but also on a register known as "Oukfia" (Waqfiyya), partially uncovered by the Domain's administration, which was the result of an early eighteenth-century survey of the habūs buildings belonging to each institution. ${ }^{65}$ It is nevertheless clear that these documents, far from being a simple expression of (highly ineffective) sovereign oversight, were actually a result of institutions and their representatives affirming (or demanding) their rights. In effect, all evidence suggests that the appointment of a wakil was largely independent of the will of the dey. One example of a conflict at the end of the eighteenth century, recounted by Devoulx, shows that other rationales had proved much more effective in determining the legitimacy of nominations. The affair brought before the qadi was a dispute between two men, of whom one was wakil of the Zawiya Sīdī Mansūr and the other a man who claimed to be replacing him. The former prevailed, both because he was related to the holy Sīdī Mansūr, founder of the oratory, and because of "the long tenure of his ancestors, which endured for many years before the moment that it fell to him." ${ }^{, 66}$ His adversary was not in a position to prove kinship with the

64. For example, Devoulx, Les édifices religieux de l'ancien Alger, 34 sq.

65. Ibid., 16; Hoexter, Endowments, Rulers, and Community, 22-23. On the interpretation of sovereign control, already defended in a report by a Domain agent in 1837, see ANOM, carton F801082, "Rapports généraux sur le Bey il mal et les corporations musulmanes," 1837: "About a century ago, following the frequent disputes that arose between the heads of religious corporations and the holders of entailed buildings, the sovereign authority conceived of a project to gather in a single volume all the donations of property made to various pious establishments that either already existed or would be created later, it being rightly felt that in order to put a stop to the often unfair claims of the wakils to the buildings that had been entailed but not definitively acquired by the corporations that they represented, and to put a stop to the bad faith of the holders, it had become necessary to ensure the authenticity of these fee tail arrangements. As a consequence, all of the properties used by pious establishments at that time were inscribed in a register named Oukfia, and the act of donation bore the signature of two Ulama as well as the seals of the Qadi and the reigning Pasha. This book, or rather this collection of donated titles, was deposited at the Great Mosque and confided to the care of the Maliki mufti."

66. Devoulx, Les édifices religieux de l'ancien Alger, 200 sq. 
saint, and, by extension, could not argue that any of his ancestors had ever held the position; he also had to admit, counter to his claim of exercising the role of wakil, that he "had never enjoyed usufruct rights [to the habūs] ... and that he did not know if any of his ancestors had ever had such rights." In practice, filiation with the founder of an institution-whether a tomb, zawiya, or mosque — was a powerful argument for legitimacy, regardless of whether the founder had specified how the post ought to be handed down. What is more, when claiming custodianship, it was also relevant to show family precedence: the hereditary element of the position was such that quite a few buildings were known not by the name of their founder but by that of the family that passed down the post. In his work, Devoulx signals the presence of these wakīl dynasties, and in 1847 the practice was ongoing. ${ }^{67}$

This conflict demonstrates that being the beneficiary of a usufruct was part of the legitimate exercise of the function of wakil. ${ }^{68}$ This indicates that the use of these assets embraced a larger sphere than that of the building's activities strictly speaking, a sphere that included all those with a claim to the benefits generated by habūs properties. Moreover, it was in actively exercising one's rights to a foundation's assets that the right to administer it could be forged. These elements offer a glimpse of an entirely different configuration surrounding the properties of these institutions and their governance. Beyond the independence (vis-à-vis a centralized power) in how positions were passed along and how religious institutions' habūs trusts were managed, the prestige enjoyed by the wakill-s existed within social spaces that were fashioned by numerous groups of beneficiaries and multiple jurisdictions that were organized around their responsibility for the habūs properties.

67. ANOM, carton F80-1087, "Lettre du directeur des finances au gouvernement général, 11 mars 1847," followed by a table showing establishments and the names of their oukils. Despite the fact that a number held their positions by virtue of their nomination by the colonial administration, in two cases we read that "the oukil died, his son has replaced him" (in this case, it was perhaps due to an administrative decision) or even "the oukil is dead, children inherit."

68. As shown in Rudolph Peters, "Waḳf," Encyclopedia of Islam, 2nd ed. (Leiden: Brill, 2009), 11:69, who makes a doctrinal argument: "the beneficiaries have the right to administer the wakf because they have the rights to the wakf property, either because they are regarded as the virtual owners of the wakf (Hanbalīs and the Imāmī $\underline{\operatorname{Sh}} \underline{1}^{\prime}$ a) or because they have the right to use and exploit (milk al-manfa'a) the wakf property (Mālikīs).” 
While the term commonly used by the French administration to designate the institutions endowed with habūs properties was "corporation," Devoulx questioned its suitability given its suggestion of "an aggregation of people living in a community or simply united by a common interest"; in his opinion, the practice of habūs ought to be considered as an individual means of circumventing the constraining rules of succession. ${ }^{69}$ While equating the institutions that managed $h a b \bar{u} s$ properties with corporations could offer a way to dismiss them as "ancien régime" organizations, it could also lead, conversely, to a dangerous recognition of rightsthose very same rights that the French administration was claiming from the Algerines. ${ }^{70}$ Certain historians have argued that the organizational forms in place in Algiers in 1830, which were sometimes reminiscent of the ancien régime, were a motive for delegitimization. Yet it is striking to note how seldom this angle of attack was used at the time. Only later was the "clash of civilizations" argument invoked; the original conflict was triggered by the struggle to monopolize local resources.

\section{An Economy of Rights of/for the City}

The reports provided by the wakil-s in response to the administrative audit reveal more than just their social importance. Their authors seize the opportunity to declare the wealth of their endowments, but each of them also points to degradations, losses, and deficits caused by

69. Albert Devoulx, Notices sur les corporations religieuses d'Alger accompagnés de documents authentiques et inédits (Algiers: Bastide, 1862), 1 sq.

70. Sami Bargaoui, "Le waqf. Redéfinitions des appartenances et inscriptions sociales," in Bargaoui, Cerutti, and Grangaud, Appartenance locale et propriété, https://doi.org/10.4000/books.iremam.3488; Engin F. Isin, "Ottoman Waqfs as Acts of Citizenship," in Held in Trust: Waqf in the Islamic World, ed. Pascale Ghazaleh (Cairo: The American University in Cairo Press, 2011), 253-79; Pascale Ghazaleh, Fortunes urbaines et stratégies sociales. Généalogies patrimoniales au Caire, 1780-1830, 2 vols. (Cairo: Institut français d'archéologie orientale, 2010); Gabriel Baer, "The Waqf as a Prop for the Social System (Sixteenth-Twentieth Centuries)," Islamic Law and Society 4, no. 3 (1997): 264-97; Jean-Claude Garcin and Moustafa Anouar Taher, "Identité du dédicataire, appartenances et propriétés urbaines dans un waqf du $\mathrm{XV}^{\mathrm{e}}$ siècle," in Valeur et distance. Identités et sociétés en Égypte, ed. Christian Décobert (Paris: Maisonneuve et Larose/MMSH, 2000), 189-95. For a comparative perspective on this process of foundation between the north and south of the mediterranean, see Simona Cerutti and Isabelle Grangaud, eds., "Fuori mercato. Appartenenze locali e beni nel Mediterraneo," special issue, Quaderni Storici 52, no. 154 (1) (2017). 
demolitions and occupations. On the whole, institutions' habūs properties had been badly damaged. Some complained of severe losses: five of the twelve buildings belonging to the Sūq as-Sman mosque had fallen into disuse, the Qshāsh mosque had been stripped of three of the six buildings initially belonging to it, and the mosque of Sīdī Flih had been reduced to the revenue from two houses and two shops, four of its other shops having disappeared. Among those buildings that no longer existed, many had fallen victim to demolition policies, especially following the creation of the government square in the lower part of the city, where its main economic and political institutions had stood. Other properties had been occupied by the military or, in several cases, alienated by the Domain. The losses were sometimes the result of collateral damage related to military seizures of properties belonging to janissaries or former Ottoman authorities, which in turn impacted third-party property rights. This is what the wakīl of the mosque of Ibn ash-Shahīd, Ahmād bin Muhammad Ghalyūndjī, was lamenting when he observed that, among the properties belonging to his mosque, a small house whose rent was due to $\mathrm{him}^{71}$ was "in the hands of the Domain, for the reason that the habūs of its land had been integrated into Dār al-Injashā'irī [the janissary barracks] upon the arrival of the French and up until today." 72 According to the principle of multi-level properties, the various parts of a property could belong to multiple people or institutions, and it was even possible for the walls of a house to be held by one party while the plot of land was a habūs property; an entanglement of rights that, until its underlying principle was dismantled, multiplied the effects of the seizure and occupation related to the conquest. Thus, the rights that the mosque of Ibn ash-Shahīd had exercised over the land under this barracks were abolished as soon as it was turned over to the Domain.

This kind of specificity regarding losses is not unusual in the reports collated in this bundle. Varying in form from one author to another, the indications given in the reports 
suggest that the wakill-s took them as an opportunity to condemn what had happened to the properties under their responsibility. Some, more discreet, soberly observed that a property had been "destroyed." Most often, however, their sense of grievance was emphatically underscored. A visual effect was used to distinguish, upon the page, active buildings from unproductive buildings. For example, two separate lists were collated for the habūs of "Mecca and Medina." The first comprised the rents of 144 gardens and farms (indistinctly grouped), while the second enumerated the rents of thirty-nine residences "that are under the soldiers'

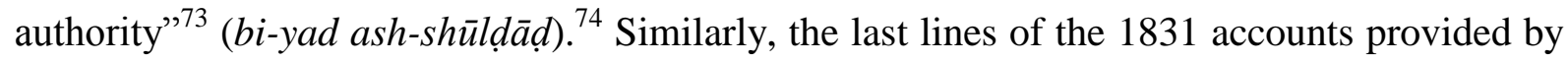
the wakìl of the subūl khayrāt are used to announce a significant deficit estimated at 5,447 pataques $^{75}$ - equivalent to more than a third of the total monthly payments from six mosques and two zawiyas - reflecting losses due to "what has been destroyed or occupied by soldiers. ${ }^{, 76}$ More broadly, numerous reports not only specify the cause of the loss, but also emphasize its duration and disruptiveness. Thus Muhammad 'Awūn, wak̄̄l of the Sidī Masbah mosque, reveals that, out of his establishment's seven habūs buildings, there is "a destroyed shop in the square (bi-sāha)" that once yielded "four [mouzoun] each month, which we have not received for the last three years." Of another shop near Bāb al-Wād, he writes, "we have received nothing [of the monthly rent] for three years," since it was placed under the authority of the Domain (al-duminn̄). "Three years later," writes the wakill of the mosque located in

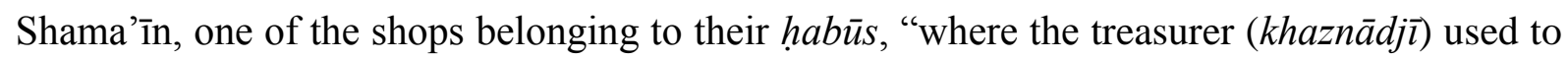
be located, today yields nothing."77

These comments—-highlighted, repeated, and emphasized — suggest that this accounting exercise was, for many authors, much more than a straightforward response to an audit; it

73. ANOM, archives of the former Regency of Algiers, reel 1Z.21, undated.

74. The use of the term shüldād, a transcription of the French word soldat, rather than the corresponding Arabic term ('askar), is itself a criticism.

75. The pataque was a money of account.

76. ANOM, archives of the former Regency of Algiers, reel 1Z.21, undated. The small amount remaining (1718 PC) was just enough to cover the material expenses and wages needed to keep the wākil office running.

77. ANOM, archives of the former Regency of Algiers, reel 1Z.21, undated. 
offered the opportunity to solicit an organized response to the chaos they were facing, due to both the scale of their losses and the huge lack of discernment that characterized colonial occupation when it came to recognizing and distinguishing respective rights. For those who ran the city's institutions, these reports were a way to publicize their grievances and provide evidence by identifying the buildings that had been destroyed or occupied and demonstrating that their rights had been violated. It is in this sense that we can interpret the words of the wakìl of Djāmi' al-Shawāsh, who alleged that their losses included the rent from an orchard, which had been "under the authority of the beylik since 1244."78 Just over a year before the conquest, the property to which the wakil laid claim had been rented to the Ottoman government under a contract that the new authorities had evidently not taken into consideration when they confiscated the property in question. This statement was accompanied by a notification of the existence of papers (qwighat) able to prove this claim. Notwithstanding the misrepresentation involved in certain cases (for example, the declaration of the wakīl of the Zanqa Lishtūn mosque, discussed below), declaring assets was thus a way to claim rights and demand justice.

During the first years of the conquest, the prospect of compensation for occupied or demolished buildings nurtured these complaints. This question had been on the agenda since the decree of January 19, 1831. A campaign of public notices in both Arabic and French realized by the Domain a year later, on February 22, 1832, reiterated a call to make reclamations before the closing date of April 1, with a promise to deliver compensation during the second half of the year. ${ }^{79}$ A year and a half later, the situation was still the subject of complaints in reports addressed, in Arabic, to the minister of war. ${ }^{80}$ There is no doubt that

78. ANOM, archives of the former Regency of Algiers, reel 1Z.21, undated. 1244 is the Hijri year corresponding to July 14, 1828-July 3, 1829.

79. ANOM, carton 1MI.21 "Avis/ 'alam" contains the bilingual draft of the notification, preserved among the Arabic archives of the Domain administration.

80. SHD, 1H20, "Mémoire de Hamdan Khodja à l'adresse du Ministre de la guerre," and "analyse et commentaires sommaires," June 1833. 
when most of the accounts were submitted in April 1833 the wakill-s were aware of this issue and were legitimate claimants. However, these declarations coincided with significant social upheaval connected both to the impoverishment of city institutions and to the aspersions cast on their guardians and preexisting modes of organization. Among the abuses attributed to the "oukils" was the practice of renting. French officials suspected them not only of making informal agreements, but also of "appropriating, by means of clandestine arrangements made with renters, a portion of revenues; of renting properties at ridiculous prices to their friends and family." ${ }^{81}$ In effect, the French administration's early audit of the properties of the two holy cities resulted in a reconsideration of how benefits and alms were to be distributed: not only did the new authorities defend their reevaluation of rents, but they also granted themselves the right to review criteria for the allocation of benefits. "The administration has shown no leniency towards rich families who pay a pittance in rent on multiple properties, enriching themselves at the expense of the poor," wrote one Domain agent in $1837 .{ }^{82}$ Yet the attempt to restrict the habūs economy to a narrow religious sphere-associating Islam with charitable duty, "the first duty imposed by religion" political aspects of this charitable economy. ${ }^{84}$

The clues that we have concerning the buildings represented by the wakill-s suggest that prospering institutions had a civic dimension far greater than their modest material presence implied. The role of the wakill-s, like the allocation of the financial and material wealth for which they were responsible, was altogether more comprehensive. These institutions were the

81. Busson de Janssens, "Contribution à l'étude des habous publics algériens," 59, citing a report of the 1833 investigative committee drawn up on January 12, 1834: "Rapport sur la fondation de La Mecque et Médine et autres établissements pieux."

82. ANOM, carton F80-1082, "Rapport sur l'administration des corporations adressé à Monsieur l'Intendant civil," 1837.

83 ANOM, carton F80-1082, "Rapport sur 1'administration des corporations adressé à Monsieur l'Intendant civil." For recent approaches to charity in Islam, see Michael D. Bonner, Mine Ener, and Amy Singer, eds., Poverty and Charity in Middle Eastern Contexts (Albany: State University of New York Press, 2003).

84. Among the "Muslim poor" considered by the Charity Office, which took over the distribution of alms from the mosques, the category of veterans (and their widows and orphans) who fought with or on behalf of the French army was given special treatment. 
principal landlords in a city where private property "was the exception rather than the rule." 85 The distribution of privileges concerning access to the urban environment, as well as to the various forms of charity that these institutions provided, was a powerful vector in the construction of social space and the allocation of resources, and was founded upon its own hierarchy. Far from simply being the managers of an economic fortune devoted exclusively to religion and worship, the wakill-s were active promoters - prescribers and guarantors - of the dynamics that formed the bedrock of the city's social and political configuration. They and their services functioned as a locus for groups, households, and systems of patronage that were specifically founded upon the (unequally) shared privilege of being associated with them. If we take the potential benefits of this system seriously, then the colonial administrators' accusations of undue favoritism, as represented by the unequal distribution of habūs usufruct for the benefit of family and friends, reflected a narrow perspective. On the contrary, kinship and acquaintance were the result of a process of forging links within a system characterized by the unequal distribution of rights to local resources, and which was itself at the root of social stratification. The battle led by the wakill-s to defend these resources and their management also contained within it a defense of civic rights. Once this battle was lost, the mosques were reduced to a narrow religious function and, soon after, to piles of old stones, thereby relegating to the shadows not only the process of delegitimization of an urban elite, but also and even more inexorably, the suppression of the rights that the community of Algiers's inhabitants exercised over its own space.

\section{Tracking the Lie: The Birth of the Ottoman Collection}

Devoulx did not draw upon a history of the wakill-s as architects of the city's civic space when he wrote The Religious Edifices of Old Algiers. His work followed in the footsteps of those

85. Shuval, "Poor Quarter/Rich Quarter," 77. 
who used the declarations by the mosque administrators to hone the weapons of their control. The few notes in French jotted here and there on the wakill-s' reports from the early 1830s suggest that the preoccupation of the Domain's agents, when they received them, was not so much to take the measure of what had been destroyed as it was to assess the value of these buildings, the extent of the properties, and, above all, the validity of the wakil-s'statements. This expertise led to the production of a vast documentation in Arabic, which was archived soon afterwards.

\section{Oversight by the Domain}

Devoulx's work never explicitly mentions the declarations collected in this bundle. When he alludes to an inventory of the mosques' properties, it is in reference to an 1834 census. Yet it is quite possible that these statements did come to his attention and that they were part of his corpus. This can be seen in his extensive discussion of the little Zanqa Lishtūn mosque. Although he seldom includes references to mosques' possessions-reserving this privilege for the largest and richest-Devoulx specifies in this case that its endowment "consisted of two houses and three shops and [that] its revenue in 1834 was 108 francs." In the statement that its wakīl, the sayyid Ahmad Ibn al-Sayyid al-hājj Muḥammad Ibn al-Amīn, had submitted the year before, he made mention of only one property, a small house, accompanied by a cryptic note: "this is what we have, praise be." It is possible that Devoulx was implicitly referring to this episode when he chose to add that the "last oukil was Mohamed ben Ali, appointed on March 8, 1837" by the Domain, probably following the eviction of the previous wakil after the fraudulence of his statement was revealed. ${ }^{86}$

While withholding information was one way of responding to administrative oversight, in a few rare cases there were struggles over claims for the full ownership of religious 
institutions. Such was the case of the little mosque of Qā' Sūr, whose wakīl in 1833 was the sayyid Muștafā, then a Hanafi qadi. Devoulx notes that "it is in the possession of an indigenous family that claims to own it. As my aim is strictly historical, I am abstaining from all commentary for or against their claim." ${ }^{87}$ Reading between the lines, we can intuit the discomfort that this claim must have provoked, though in all logic it could not be dismissed. This was also the case with the Zawiya Ayoub, whose wakil, who had signed the 1833 declaration, descended from the saint on whose tomb it had been founded. Devoulx specifies that the decision fell to the "administration, which considered this establishment the private property of the Youb family, for whom the role of oukil was hereditary and who promptly relinquished the zawiya of their forefathers for the benefit of a few Europeans." ${ }^{88}$ The criticism, in this case veiled, is more explicit on the subject of the formal attribution "by the administration" of the al-Abbassī zawiya (which had not been the subject of a declaration in 1833 ) to the family associated with it, who similarly sold it to a European. Devoulx writes:

Some people have severely criticized the administration for demolishing or confiscating mosques that were threatening ruin or that stood in the way of plans for the beautification and sanitation of the city. They ought to recall, as in the case of the zaouiet al-Abbassī, that when the natives were left in full possession of the buildings, reserved for burials and prayer, they generally had no qualms about turning them over to Europeans and sacrificing religious traditions to their own interest. I could provide several examples. One should therefore not push one's scruples too far and look to be more Mohammedan than the Muslims themselves. ${ }^{89}$

There were not many other options. By 1870, according to Devoulx's book on the buildings that, in 1833, the wakill-s had claimed to manage, only three establishments out of all the small mosques and zawiyas still retained their devotional purpose. Some of them had been demolished for the expansion of other structures or the creation of new roads; others were

87. Ibid., 79.

88. Ibid., 130.

89. Ibid., 247. 
occupied by new institutions and services. Most of the buildings, however, had been confiscated or demolished within a few years as a result of their abandonment, disrepair, or ruined state. Apart from the zeal associated with projects to beautify the city, this fate ought to be understood, much more than it has been in the past, as part of the intense weakening of the economy caused by the destruction of the habūs trusts.

Devoulx's perspective, that of a censor, simply reproduced the attitude that successive agents of the Domain must have adopted before him in the exercise of their duties. Indeed, by participating in this vast project to survey and authenticate the habūs heritage of the city's institutions, the Arabists of this administration helped create an incredible mass of documentation. A great many lists were compiled to take stock of these properties: these were professional tools that served at once to facilitate research on the ground, establish evidence, and, ultimately, create classifications in order to build up the Domain's registers and files. Among these writings, two registers, established at an undetermined date under the title of "Religious establishments," recorded the appropriation of the habūs (in some cases still growing) of 118 institutions. ${ }^{90}$ By considering their content, it is possible to grasp the logic of these records.

The acknowledgment of these properties was in reality an acknowledgment through their documentation: various records were compiled for each institution, numbered, and, when sufficiently numerous (which was not often), arranged spatially. ${ }^{91}$ The primary source of this documentary material was clearly the famous "Oukfia" (Waqfiyya). Its influence can be

90. ANOM, archives of the former Regency of Algiers, reel 1MI70, register 19, "Établissements religieux no. 1" (200 pp.) and register 20 "Établissements religieux no. 2" (24 pp.). In addition to mosques, zawiyas, tombs, and other structures, these records included the habūs of fountains, or of "students" (tulba).

91. The construction of this spatial ordering, in particular the hawma (neighborhoods), is analyzed by Isabelle Grangaud, "Masking and Unmasking the Historic Quarters of Algiers: The Reassessment of an Archive," in Walls of Algiers: Narratives of the City through Text and Image, ed. Zeynep Çelik, Julia Clancy-Smith, and Frances Terpak (Los Angeles/Washington: Getty Research Institute/University of Washington Press, 2009), 179-92; Isabelle Grangaud, "Hawma," in L'aventure des mots de la ville à travers le temps, les langues et les sociétés, ed. Christian Topalov et al. (Paris: Robert Laffont, 2010), 573-76. 
recognized in two ways: these entries specify only the nature of the property and the name of the donor, and were the first to be recopied. This source was supplemented by other documents, or rather by summaries of other documents-themselves piecemeal and sometimes very old - whose content made it possible, in one way or another, to identify the institutions' property rights. These could be legal records held by the institution itself. In other cases, the initiative mobilized documents created for another purpose and probably held by individuals, which provided only indirect proof of a link between a building and an institution. These include, for instance, bills of sale for shares of a building that was held in sole ownership, but a portion of which had already been made part of a habūs. ${ }^{92}$

This profusion of writing in Arabic allows us to concretely grasp the work of the Domain's agents on the ground and to recognize how their familiarization with the "authentic documents" gathered in large numbers (and their compilation) played a role in their oversight of both properties and people. These registers supported identifiable procedures as part of a targeted search; the notations in French that punctuate the pages show the process of reclassifying properties, which were first resituated (using their Ottoman toponyms) within the new road system created by the colonial authorities before being recopied into a series of building registries, this time in French. This method of tracking was a defense against possible objections; it avoided any consideration of the transformations that buildings might have undergone in favor of a systematic collation structured to reflect the priorities of the Domain. It also demonstrates the same characteristics as Devoulx's The Religious Edifices of Old Algiers: the same decontextualized use of "authentic documents," the same form of classification.

\section{Archiving: Turning the Page}

92. For instance, ANOM, archives of the former Regency of Algiers, reel 1MI70, undated, on the jāmi' al-Blāt (establishment no. 5). 
The bundle containing the roughly forty leaflets of declarations made by the wakil-s in the early 1830 s was a tiny part of a much larger body of writings that were collected, summarized, indexed, and classified according to the imperatives of colonization, and which accumulated to form a considerable documentation in Arabic attesting to over twenty years of activity by the Domain's agents. When Devoulx was assigned to the Office of Arabic Archives in 1848 to enact the decree ordering the absorption of all habūs into the Domain, he became the final participant in this vast undertaking. While his talents and the rigor with which he applied himself to his task were certainly acknowledged, he himself admitted to its relative simplicity: "charged with implementing this decree for the city and suburbs of Algiers, I encountered neither resistance nor objection from any quarter. The oukils relinquished the management that they had so long defended and handed over to me, without difficulty, the information and documents that they were bound to provide." 93 Four years later, the project was completed and Devoulx took on a new mission. From 1852, he headed the creation of the Domain's Arabic archives, which would gradually migrate from the Domain administration to the general government archives. He devoted many years to this work, registering the final documents in the early 1870s. A hundred years later, following Algerian independence, when the collection initially cataloged by Devoulx was moved to the Algerian national archives, this mass of documents came to be called the "Ottoman collection." 94 If these documents were mistaken for a straightforward collection of Ottoman archives, it is because the classification systems created by the Domain's agents had willingly appropriated — and transformed — categories used within the Ottoman documents themselves. For a long time, this choice obscured the essentially colonial origin of the collection.

93. Albert Devoulx, “Les édifices religieux de l'ancien Alger,” Revue africaine 39 (1863): 164-92, here pp. 187-99.

94. A microfilm has been conserved in the ANOM. Fouad Soufi, "Les archives. Une problématique de patrimonialisation," in "Patrimoine(s) en question," special issue, Insaniyat 12 (2000): 129-48. 
What is more, the archiving of this documentation was hardly a neutral event in the conflictual historical moment during which it was formalized. With the start of the French Second Empire in 1852 began the era of the "Arab Kingdom," a period that historians have long viewed as a respite before the implacable new order of colonial modernity. The compiling, ordering, and classification of the Arabic archives into a "collection," however, was a significant blow to the legitimacy of those who had been dispossessed by the French conquest. Indeed, this operation participated actively in consigning their history, and with it the battle fought over their old, now obsolete rights, to a distant past.

What, then, was Devoulx's purpose in writing The Religious Edifices of Old Algiers? Both during his search for records to "support the claims of the state" and in the course of assembling the archive, Devoulx benefited from a privileged milieu that afforded him access to the documents he needed to produce his volume. His book therefore did not exist apart from the violence and power dynamics that had made these documentary activities possible. In this sense, Devoulx's work was a beautiful and monumental burial of what old Algiers had been, made in the image of the few vestiges still standing when he published it. A different history of the buildings of Algiers was possible, but he did not write it. In light of his work as a Domain agent and then as an archivist, both of which implied a process of fragmentation, the production of this book in 1870 was more than a simple stroll through the city of Algiers and the documents that recorded it: it can be read as the account of a new owner inspecting his property, a claim that these poor mosques were no longer in any position to contest.

Reconstructing Devoulx's activities in their historical moment has allowed us to pursue a twofold archaeological effort to understand the process of creation (and intrication) of his historical work, on the one hand, and the constitution of the archive that became the "Ottoman collection," on the other. This reconstruction has unearthed the site of a forgotten battle, a power struggle whose dramatic outcome paradoxically obscured its motive and protagonists. 
It has revealed the effects of a virulent confrontation at the heart of the process of colonialization that played out through the disputed appropriation of one of the foundational economic, social, and political organizations of the Ottoman city, the habūs. A close examination of the modalities of this struggle makes it possible not only to identify links between documentary sources hitherto considered separate from one another, but also to shed light on the true nature of their contents. Both Devoulx's learned work and the archives, which would become one of the principal monuments to the precolonial past of independent Algeria, were created in the context of a struggle over competing rights to the city, and, as active protagonists in this dynamic, they drew their meaning and perspective from it.

This article has sought to understand, in the very origins of these sources, the confrontations that presided over their production and that made them legitimate, necessary, urgent, or desirable. ${ }^{95}$ It was therefore not imperative to consider the sources according to their genre (literary or archival, scholarly or administrative), nor to clearly distinguish in advance their linguistic or sociological identities or even those of their authors. Neither was it necessary to attempt an "equal" distribution" of documentary materials originating in two supposedly preexisting worlds; pursuing such parity would have meant recognizing this coexistence as a tangible reality, when it was in fact a construct of colonial reality. This study has shown the extent to which the subsequent reclassifications of these sources have ignored the entanglements of their historicity and the coproduction of materials, preferring instead a

\footnotetext{
95. Simona Cerutti, "Microhistory: Social Relations Versus Cultural Models? Some Reflections on Stereotypes and Historical Practices," in Between Sociology and History: Essays on Microhistory, Collective Action, and Nation-Building, ed. Anna-Maija Castrén, Markku Lonkila, and Matti Peltonen (Helsinki: SKS/Finnish Literature Society, 2004), 17-40; Angelo Torre, "“Faire communauté.' Confréries et localité dans une vallée du Piémont (XVII'-XVIII siècle)," Annales HSS 62, no. 1 (2007): 101-35; Isabelle Grangaud, "Premessa," in "Società post-coloniali: ritorno alle fonti," special issue, Quaderni storici 43, no. 129 (3) (2008): 563-74; Filippo De Vivo, "Cœur de l'État, lieu de tension. Le tournant archivistique vu de Venise (XV ${ }^{\mathrm{e}}-\mathrm{XVII}$ e siècle)," Annales HSS 68, no. 3 (2013): 699-728; Simona Cerutti and Isabelle Grangaud, "Sources and Contextualizations: Comparing Eighteenth-Century North African and Western European Institutions," Comparative Studies in Society and History 59, no. 1 (2017): 5-33.

96. Bertrand, L'histoire à parts égales; Romain Bertrand, Le long remords de la conquête. ManilleMexico-Madrid : l'affaire Diego de Ávila (1577-1580) (Paris: Éd. du Seuil, 2015).
} 
black-and-white reallocation of cultural identifiers, with no regard for the reality of their contents. On the contrary, it is through an understanding of their production and their uses that the sources can, more reliably, reveal their nature and scope. By considering the act of protest inherent to each one, I have sought to reconstruct the conflicts and struggles, as well as the antagonisms, that presided over their formalization. Tethering my analysis to these struggles, in this context, has made it possible to open up certain spaces and historicities, breaking free of the constraints of a narrow colonial temporality and inscribing it in a continuum that is more consistent with contemporary experience of that moment. This reading of the sources, which crosses a historical endeavor with Ottoman documents, has unearthed a forgotten moment, shattered to fragments by sources that until now were considered safe and compliant, when in fact they had once been formidable weapons.

Isabelle Grangaud Centre Norbert Elias (CNRS-EHESS-Avignon Université-AMU) Marseille, France 